\title{
The disrupted workplace: are the digital and group skills needs of employers being addressed by universities?
}

\author{
Pauline A.M. Bremner \\ Robert Gordon University, UK \\ Audrey Laing \\ Robert Gordon University, UK
}

\section{Abstract}

Upskilling moves quickly in today's 'disrupted' workplace, and skill sets need to change to meet the needs of the digital economy (Gray, 2016), sometimes referred to as the fourth industrial revolution (4IR). Using a mixed methods approach and drawing on data from relevant stakeholders, the aim of this research is to explore, evaluate and identify any mismatch between degree learning outcomes and employability skills. The research also proposes specific strategies to address identifiable skills gaps. Focusing on the views of Fashion Management (FM) alumni, the study highlights gaps in digital skills as well as gaps in professional /group skills which some alumni felt were missing from their university education. The research also notes the importance of digital skills in the workplace from the employers' point of view. This strengthens the argument for employers and universities to work more symbiotically to address any gaps between degree outcomes and employability skills in order to provide graduates who are 'work ready' for 4IR.

Given the findings, the authors recommend that the data gathered be used not only to inform and enhance our FM degree, but perhaps more importantly, and in a broader educational and academic context, that universities be mindful that they fully address the changing skills requirements of future employers. While this research focuses on FM alumni and employers, because of the creativity and management which are core to this course, the findings are relevant across many related management and creative industries university courses.

Keywords: employability; groups; skills; digital; future. 


\section{Introduction}

The stimulus for investigating this topic was previous research by Crebert et al. (2004) and Bennett et al. (2016), who discussed the development of generic skills at university, as well as research conducted by Hinchliffe and Jolly (2010), Wilton (2012), Jackson (2014) and Bremner (2017) on the issues of university degrees meeting the needs of industry. It is important to note that there is a dearth of research examining digital/IT skills specifically in the fashion domain. The disruption of workplace skills is also addressed, since digital and professional skills are now expected in many workplaces (Jackson and Chapman, 2012; Gallardo-Echenique et al. 2015). Norton's (2016) Higher Education Academy report highlights the need to embed employability into university degrees, and Bennett et al. (2016) discuss the strategies required by universities in order to achieve this. O'Leary (2017) highlights the variety of approaches to embedding employability across disciplines and universities.

With 4IR on the horizon, many reports (ECORYS UK, 2016; Gray, 2016; Bennett, 2016) note a change in skills, which academics must consider for students, 'enabling each to succeed in a rapidly changing workplace' (Hounsell, 2011, p.2). However, at degree level, the feedback which course teams tend to receive is from Student Evaluation Questionnaires (SEQs), the National Student Survey (NSS) and the Destinations of Leavers from Higher Education (DLHE). This data is often extrapolated to produce analytics and generate league tables which are used in the external environment in order to benchmark courses and universities. Notwithstanding this, the most proactive educational institutes collaborate with employers to share best practice in the area of employability and transferable skills, whilst being considerate of the QAA benchmarks for degrees. Although our four-year BA Honours Fashion Management (FM) course at Robert Gordon University achieves high course satisfaction rates, there was neither recent empirical research to support course developments nor an Institutional Led Subject Review (ILSR).

Part of the responsibility of being head of year for stage 4 (final year) FM students, is to prepare a Professional Skills Enhancement Programme (PSEP). In collaboration with colleagues from our university's Employability and Professional Enrichment Hub (EPE), the PSEP provides sessions which consider the transferability of skills, encouraging the 
students to reflect and be more aware of the skills they have developed over the course of their studies. Taking these elements into account the aim of this paper is to explore and evaluate a possible mismatch between the FM degree-level learning outcomes (LLOs) and employability skills required in an increasingly 'disrupted workplace'. The objectives are:

- To review the relevant academic and educational literature on current and future graduate skills requirements.

- To investigate skills gaps via a mixed methods approach with a range of relevant stakeholders.

- To develop strategic recommendations to ensure any skills gap between academia and industry is addressed.

\section{Literature review}

First destination employment for any graduate is challenging, as competition is high (High Fliers, 2018). The employment rates of graduates are often presented in league tables, with many universities strategically outlining the importance of the professional employability of its alumni. However, skills requirements are evolving (Crebert et al., 2004; Bennett et al., 2016; Hamill, 2018) meaning changes are necessary to ensure future graduates are 'work ready'. Gray (2016) notes the top 10 skills required for 2020 (Table 1). With the many challenges in respect of $4 \mathrm{IR}$, the repurposed vision of universities must evolve.

Table 1. The top ten skills for 2020 and 2015 from the World Economic Forum (WEF) (2018) and Gray (2016).

\begin{tabular}{|c|c|}
\hline Skills for 2020 & Skills for 2015 \\
\hline 1. Complex Problem Solving & 1. Complex Problem Solving \\
\hline 2. Critical Thinking & 2. Coordinating with Others \\
\hline 3. Creativity & 3. People Management \\
\hline 4. People Management & 4. Critical Thinking \\
\hline 5. Coordinating with Others & 5. Negotiation \\
\hline 6. Emotional Intelligence & 6. Quality Control \\
\hline
\end{tabular}




\begin{tabular}{|l|l|}
\hline $\begin{array}{l}\text { 7. Judgement and Decision } \\
\text { Making }\end{array}$ & \begin{tabular}{l} 
7. Service Orientation \\
\hline 8. Service Orientation
\end{tabular} \\
\hline 9. Negotiation & $\begin{array}{l}\text { 8. Judgement and Decision } \\
\text { Making }\end{array}$ \\
\hline 10. Cognitive Flexibility & 9ctive Listening \\
\hline
\end{tabular}

Pressure has grown for students to differentiate themselves from the wider student body (Walker, 2014) and the requirement for 'employability skills' to be intrinsically part of degree programmes has strengthened (Norton, 2016; Bennett et al., 2016; O'Leary, 2017). Many reports have highlighted the need for digital skills/literacy (DS/DL) to be incorporated into learning contexts (Hounsell, 2011; Laurillard et al., 2016; ECORYS UK, 2016; Scottish Government, 2016) or the work sphere (Price Waterhouse Cooper, 2018). Whilst the meaning of 'digital literacy' is not stable (Gallardo-Echenique et al., 2015), leading some to favour the term digital competence (Ferrari, 2012), it has been identified as a necessity for all jobs (Laurillard et al., 2016). Yet the CBI (2017) has noted weaknesses in employee IT skills, a point echoed by ECORYS in 2016. Jisc describes digital literacy (DL) as 'those capabilities which fit an individual for living, learning and working in a digital society' (Jisc, 2014). They extend the 'seven elements' of DL (digital scholarship, information literacy, media literacy, communications and collaboration, career and identity management, ICT literacy, learning skills) with the inclusion of Beetham and Sharpe's framework (2010) encompassing four areas: access and awareness, skills, practices, and identity, thus providing a starting place for many institutions in terms of degree DL integration. The Employability in Scotland forum (2017) have stressed a 'collective approach to skills must continue' as the necessity for digital skills becomes 'vital to the economic development, internationalisation and innovation' of Scotland (Skills Development Scotland, 2019). A hidden pipeline of talent is identifiable in non-computing sectors such as the creative industries.

Notwithstanding this, the top ten skills (Table 1 ) include professional skills, with numbers 4-6 for 2020 involving people to some extent. It is vital, therefore, to realise that even in the digital workplace, professional skills and interpersonal expertise are vital. For example, traditional communication roles are being repackaged as Digital Storytellers. A recent 
search on Linkedln found 293,230 people with job titles incorporating that type of description (Linkedln, 2018). Working effectively with people is still as important as ever (CIPD, 2017; 2019). Indeed, a popular web site for jobs, Monster.co.uk (2018), commonly cites personal effectiveness and relationship management as employee requirements. Many authors have highlighted the necessity for the transferability of graduate skills which are not discipline-specific (Maguire and Guyer, 2004) or fixed (Hinchliffe and Jolly, 2010), and that graduates' experiences of employer-based support during degrees varies by discipline and gender (O'Leary, 2015). Bremner (2017, p.3) found that 'traditional graduate skills have to be transferable and attribute-based inclusive of communication and interpersonal skills, team working, intellect and problem solving, critical and reflective ability, adaptability and risk-taking if organisations are to 'proact' to change'. Professional skills can often be incorporated into teaching through team work (Bennett et al., 2016), presentations, workplace experience (O'Leary, 2015) and working with clients on coursework. The communities for practice framework C4P (Hoadley and Kilner, 2005) is noted (Bremner, 2017) as a useful team work model for incorporation into modules as it works 'by emulating the activities of industry teams on group projects' (Hoadley and Kilner, 2005, p. 53). Additionally, holistic approaches are reinforced by Black (2013), who cites stamina, dealing with people of all ages and cultures, and managing upwards as key aspects of the workplace. This strengthens the argument that students have to be lifelong learners (Harvey et al., 1997; Jenkins et al., 2002; Hinchliffe and Jolly, 2010; Laal and Salamati, 2012).

Often, some of these 'skills and competencies' mentioned are embedded through the inclusion of team work in module assessments (Lave and Wenger, 1991; HodgkinsonWilliams et al., 2008). Hoadley and Kilner (2005) note that group work provides underpinning for 'social learning' which incorporates the communities for practice framework C4P. Although grounded in research undertaken in the IT field, the C4P model elucidates the development of four stages (Figure 1) and a context which can be used 'by emulating the activities of industry teams on group projects' (Hoadley and Kilner, 2005, p. 53). 
Figure 1. The C4P framework for emulating an IT consultancy of community of practice (Hoadley and Kilner, 2005, p. 53)

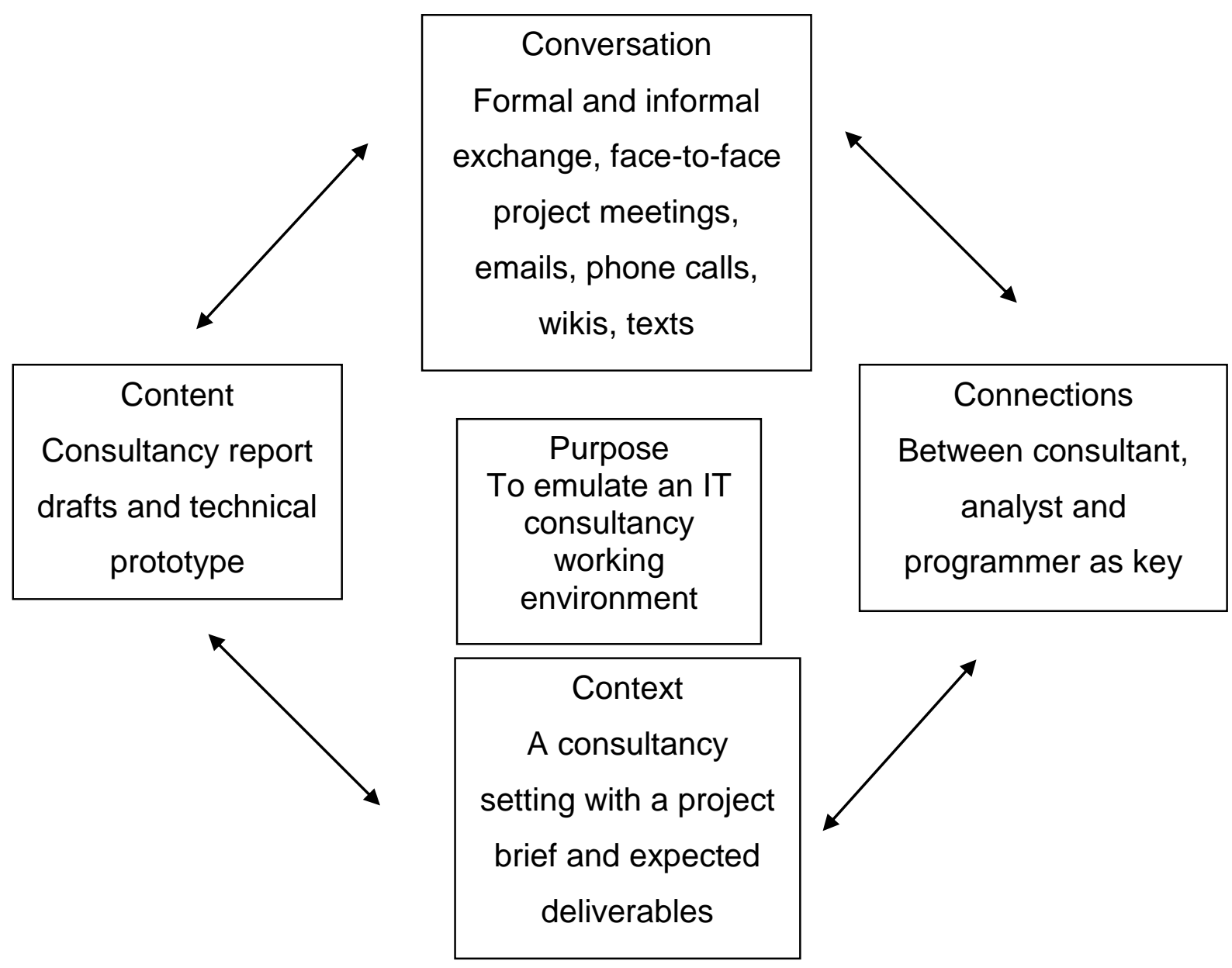

Fearon et al. (2012) also highlight team work as being 'increasingly recognised as a way for students to problem solve and demonstrate transferable skills necessary for the workplace' (2012, p.114). Comparing the skill sets from Table 1 (Gray, 2016, WEF, 2018) and Figure 1 (Hoadley and Kilner, 2005), Table 2 indicates the dominance of transferable/professional skills is clear, permeating almost all of the skills from WEF (2016) and most obvious in the 'Conversation' and 'Connections' skill summaries from Hoadley and Kilner (2005). 
Table 2 - Skills framework adapted from Future of Jobs Report, World Economic Forum (WEF) (2018), and Hoadley and Kilner (2005)

\begin{tabular}{|c|c|}
\hline Skills (From WEF, 2018) & $\begin{array}{l}\text { Skills (Hoadley and Kilner, } \\
\text { 2005) }\end{array}$ \\
\hline Service Orientation & \multirow[t]{3}{*}{ Content } \\
\hline Quality Control & \\
\hline Complex Problem Solving & \\
\hline Critical Thinking & \multirow[t]{3}{*}{ Context } \\
\hline Creativity & \\
\hline Judgement and Decision Making & \\
\hline Active Listening & \multirow[t]{3}{*}{ Purpose } \\
\hline People Management & \\
\hline Negotiation & \\
\hline Cognitive Flexibility & \multirow[t]{2}{*}{ Conversation } \\
\hline Coordinating with Others & \\
\hline Emotional Intelligence & Connections \\
\hline
\end{tabular}

The BA Honours FM course is designed to take into account the QAA benchmarks, Scotland's Quality Enhancement Framework (QEF), the Enhancement-Led Institutional Review (ELIR) and the Teaching Excellence Framework (TEF). Employers' viewpoints are also addressed using liaison committees attended by academia and relevant industry members. The BA (Hons) Course has consistently achieved a course satisfaction rating of over $80 \%$ from the NSS with a $100 \%$ satisfaction rating in $2015-2016$. However, the fashion sector is constantly undergoing change and is one of the largest contributors to the UK economy with a market value of 66 billion pounds in 2018 (FashionUnited, 2018). Globally, consumption patterns and the introduction of digitisation practices such as 3D printers and artificial intelligence for supply chains, is disrupting fashion employment, whilst many consumer reports highlight the need for 'market prioritisation' as a strategy for survival (Euromonitor, 2017; 2018).

The importance of employers and universities working together cannot be underestimated given the skills priorities emerging from research (O'Leary, 2015; Bennett et al., 2016), which suggests that the gap between degree outcomes and employability skills may have 
to be identified more quickly if the education sector is to be competitive. Students' transferable skills are often highlighted in graduate skills attributes frameworks by some universities (e.g. Glasgow, Oxford Brookes, Leeds Beckett) to enhance students' and employers' understanding of the skills and competencies gained from a degree. This is the case in the Jisc digital literacies programme, which highlights 'learner literacies and strategic approaches to their development and support' (Jisc, 2014). As jobs become more transient, skills enhancement and employee development for 4IR will become more streamlined and connected to the workplace (Hinchcliffe, 2018), enhancing the student learner journey in any degree programme. This in turn leads to the concept of developing a unique business process model in collaboration with employees, to be incorporated into each degree, similar to strategies suggested by Bennett et al. (2016). It has to be noted, however, that 'lifelong learning' has to adapt (Laurillard et al. 2016; Gray, 2016; World Economic Forum, 2018) and a rethink of education systems has been recommended (Gray, 2016). Additionally, it highlights the importance of education for sustainable development and associated flexible pedagogies which will provide students with transferable skills for an unknown future.

In examining any potential gaps between the FM degree outcomes and employability skills required, feedback from SEQs and NSS were consulted. In addition, this study uses empirical data to extend and enhance knowledge about potential skills gaps, focusing on data from university alumni and employers. Phase one of the research used a mixed methods approach, whilst phase two was solely qualitative.

\section{Methodology}

The methodological approach adopted a two-phase mixed methods process, which allowed for the breadth and depth of the topic to be examined. Phase one adopted a comprehensive four-stage process (Bremner, 2017) of focus groups, interviews, an equestionnaire and follow up interviews. Phase two, undertaken eight months later, involved interviewing eight employers as well as key university support staff with career development responsibilities (Figure 2). All stages took into account the requirements of the university's ethics policy, and informed consent was obtained. 
Figure 2. The methodological stages
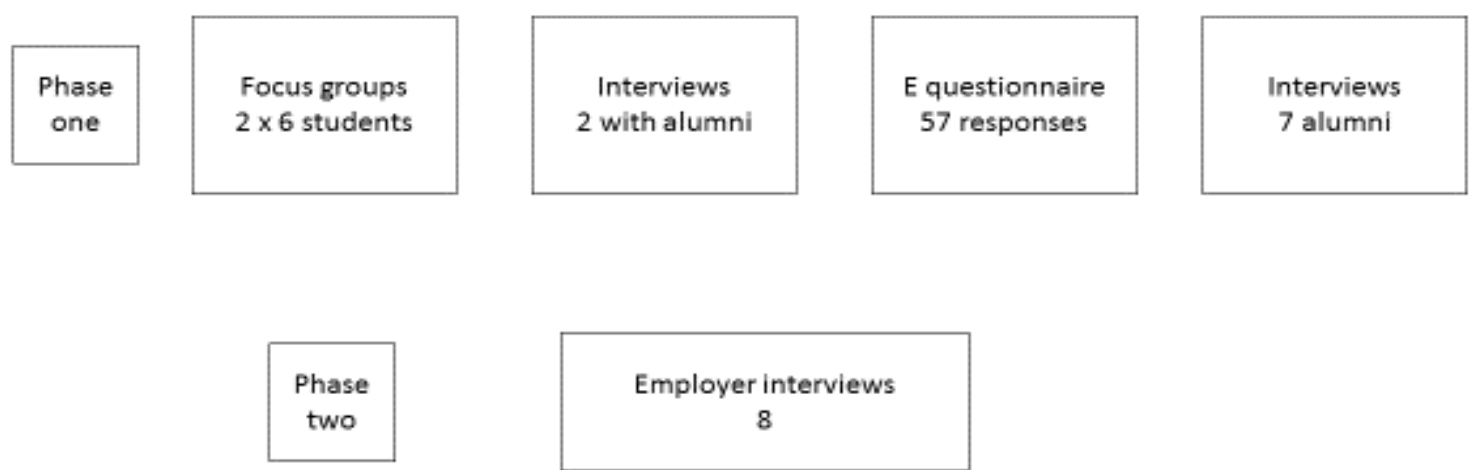

Employer interviews

8

In order to develop an understanding of the transferability of the degree skills in the FM course, a convenience sample of stage four honours students was selected to take part in two focus groups. The focus groups $(n=2 \times 6)$ examined the students' return from workplace experience to university, and any skills gaps they had noted while working in the industry. This interpretivist approach allowed for exploration of their individual experiences (Bryman and Bell, 2015). Post thematic analysis (Bryman, 2008) highlighted two areas which needed further examination: group/professional and digital skills. This was subsequently addressed with two alumni using in-depth interviews. A focused approach was adopted in these interviews, discussing the degree-level learning outcomes of the course in order to identify how well skills had transferred and to further probe the two areas of group/professional and digital skills highlighted. Themes emerged from these interviews which were similar to those highlighted from the stage four FM students, that is group/professional skills and digital skills.

An online questionnaire (Table 4) was subsequently developed introducing a positivist element to the research (Saunders et al., 2016). The questionnaire examined personal data and explored the use of the modified level learning outcomes using a 5-point Likert scale (Strongly Agree to Strongly Disagree). The questionnaire also probed participants' opinions on the missing skills identified at the earlier qualitative research phase. The final section of the questionnaire focused on the use of university training provisions for easing graduates' transition into the workplace. Post pilot (Bell, 2010), the questionnaire was distributed to 122 alumni garnering a response rate of $46 \%(n=57)$. From the 
questionnaire returns and means analysis, follow up one-to-one interviews $(n=7)$ were conducted, allowing for objective interrogation (Denscombe, 2014).

Table 4. Questionnaire themes.

\begin{tabular}{|c|c|}
\hline Theme & Questions asked \\
\hline 1 & Four personal demographic type questions about the course \\
\hline 2 & $\begin{array}{l}\text { Four questions on knowledge and understanding of the specific areas of } \\
\text { fashion management in relation to the course-level learning outcomes. } \\
\text { (Three Likert scale questions and one open question) }\end{array}$ \\
\hline 3 & $\begin{array}{l}10 \text { questions on practical skills usage in the workplace in relation to the } \\
\text { course-level learning outcomes. } \\
\text { (Nine Likert scale questions and one open question) }\end{array}$ \\
\hline 4 & $\begin{array}{l}\text { Nine questions on intellectual skills used in the workplace in relation to } \\
\text { the course-level learning outcomes. } \\
\text { (13 Likert scale questions and one open question) }\end{array}$ \\
\hline 5 & $\begin{array}{l}\text { Six questions on key employability and transferability of skills to the } \\
\text { workplace in relation to the course-level learning outcomes. } \\
\text { (Five Likert scale questions and one open question) }\end{array}$ \\
\hline 6 & $\begin{array}{l}\text { Five questions on skills students feel they need more of in relation to } \\
\text { skills gaps highlighted from the qualitative feedback. } \\
\text { (Four Likert scale questions and one open question) }\end{array}$ \\
\hline 7 & $\begin{array}{l}14 \text { questions in relation to the use of university training provisions for } \\
\text { personal development. } \\
\text { (12 Likert scale questions and two open questions) }\end{array}$ \\
\hline
\end{tabular}

Phase two of the research involved semi-structured interviews $(\mathrm{NI}=8)$ with employers in the fashion and food marketing sectors, as well as interviews with key professional support service employees working in student employability roles within the university (Table 5). Here the content of the interviews focused more on the importance of digital skills in the workplace as a key theme identified from the evolution of $4 \mathrm{IR}$. 
Table 5. Sample of employers interviewed with themes of interviews highlighted.

\begin{tabular}{|c|c|c|c|}
\hline Business type & Job role & Business Focus & Themes \\
\hline 1. Marketing/SME & Owner & $\begin{array}{l}\text { Social } \\
\text { communication }\end{array}$ & \multirow[t]{2}{*}{$\begin{array}{l}\text { What are } \\
\text { digital skills? }\end{array}$} \\
\hline 2. Marketing/SME & Owner & $\begin{array}{l}\text { Social } \\
\text { communication }\end{array}$ & \\
\hline $\begin{array}{l}\text { 3. Food agency/ } \\
\text { Government body }\end{array}$ & $\begin{array}{l}\text { Communication } \\
\text { Manager }\end{array}$ & $\begin{array}{l}\text { Food and } \\
\text { marketing }\end{array}$ & \multirow{2}{*}{$\begin{array}{l}\text { What is the } \\
\text { importance o } \\
\text { digital skills? }\end{array}$} \\
\hline 4. Manufacturing/SME & IT director & Fashion & \\
\hline 5. Design agency SME & $\begin{array}{l}\text { Design } \\
\text { consultant }\end{array}$ & Fashion & \multirow{2}{*}{$\begin{array}{l}\text { Training and } \\
\text { development } \\
\text { within the } \\
\text { interviewee's } \\
\text { particular } \\
\text { business }\end{array}$} \\
\hline 6. University & $\begin{array}{l}\text { Manager / } \\
\text { careers }\end{array}$ & Higher Education & \\
\hline 7. University & $\begin{array}{l}\text { Manager / } \\
\text { workplace }\end{array}$ & Higher Education & \multirow{2}{*}{$\begin{array}{l}\text { The value of } \\
\text { higher } \\
\text { education } \\
\text { degrees. }\end{array}$} \\
\hline 8. Marketing SME & Joint owner & Marketing & \\
\hline
\end{tabular}

\section{Limitations}

The authors recognise that while there has been a considerable amount of research conducted, there are limitations such as the small sample sizes at some stages of the study and the focus upon a single degree within one institution. The study would need to be replicated for other similar courses and universities to validate the findings on a larger scale.

\section{Findings/discussion}

With such a range and amount of data collected, only the key findings are reported here. Two themes are included: the gap between employability skills delivered on the FM degree 
and those required in the workplace, and the digital skills gap. Finally, the relevance of using mixed methods research to enhance student employability will be discussed.

\section{The gap between employability skills delivered on the FM degree and those needed in the workplace}

From phase one of the research, there was overwhelming support for the fact that a majority of degree skills delivered had transferred to placement and first destination employment whether in fashion-related jobs or not. The FM degree was noted by all for its diversity providing a good grounding for employment upon graduating (Bremner, 2017).

A similar pattern was identified from the e-questionnaire where a number of the degree's LLOs were positively skewed (Table 6). These included aspects of employability, transferability and enterprise skills, supporting the fact that the FM degree has a high course satisfaction rate (NSS 2017), and that some skills transfer effectively when embedded into degrees (Crebert et al., 2004; Norton, 2016).

LLOs from the questionnaire which did not fare as well included development of digital, group and professional skills. This point was supported by the alumni interviewees $(n=7)$ from the first phase of the research process. A range of 'digital literacy' points were noted, such as the use of Photoshop, Excel, creation of digital portfolios, app development and mail chimp use. Interviewee 1 highlighted the need 'for a range of digital ability within graduates who should be able to use mail chimp and Photoshop'. However, Interviewee 4 pointed out that 'more of these 'digital skills may have been incorporated' since their own graduation' suggesting there may no longer be a gap (Bremner, 2017, p.4).

Two students from phase one of the research stated that they did not feel ready for working in groups while on workplace experience, implying that this particular skill set had not transferred as well. Participant 1 from focus group one said: 'I think it is something which will only come from experience'. Participant 3 stated that 'workplace experience, oral presentations and working with "real clients" aided professional /group skills development, and although students do not relish group work, they realise the benefits'. This point was noted by more than one of the alumni interviewees. The group work 
included professional skills such as managing conflict and negotiation, team work, and communicating in groups.

Table 6. Means ratings of the statements relating to the LLOs of the course (statements adapted from the course LLOs).

\begin{tabular}{|c|c|}
\hline Statement & $\begin{array}{l}\text { Mn } \\
\text { Score }\end{array}$ \\
\hline $\begin{array}{l}\text { Four questions on knowledge and understanding of the specific } \\
\text { areas of fashion management in relation to the course-level learning } \\
\text { outcomes. (One question was open and not noted here) }\end{array}$ & \\
\hline $\begin{array}{l}\text { I have a clear understanding of the application of fashion management } \\
\text { within my current job role }\end{array}$ & 1.8 \\
\hline $\begin{array}{l}\text { I am confident and familiar with defining concepts, features within my work } \\
\text { role }\end{array}$ & 1.8 \\
\hline I can apply research methods/skills in my current role & 1.6 \\
\hline $\begin{array}{l}10 \text { questions on practical skills usage in the workplace in relation to } \\
\text { the course-level learning outcomes. (One question was open and not } \\
\text { noted here) }\end{array}$ & \\
\hline $\begin{array}{l}\text { I can engage effectively via communication methods and presentation } \\
\text { techniques in my workplace }\end{array}$ & 1.2 \\
\hline $\begin{array}{l}\text { I can engage professionally via communication methods and presentation } \\
\text { techniques in my workplace }\end{array}$ & 1.3 \\
\hline $\begin{array}{l}\text { I can produce detailed critiques and projects within a wide range of } \\
\text { contexts in my job role }\end{array}$ & 1.6 \\
\hline I am able to use numeracy skills competently & 1.5 \\
\hline $\begin{array}{l}\text { I am able to use a variety of computer-based packages to manipulate and } \\
\text { present data in an appropriate manner }\end{array}$ & 1.5 \\
\hline $\begin{array}{l}\text { I can manage my own learning within my workplace, seeking out and } \\
\text { making use of feedback }\end{array}$ & 1.3 \\
\hline $\begin{array}{l}\text { I can interact effectively in a variety of group situations within my } \\
\text { workplace teams }\end{array}$ & 1.2 \\
\hline I am able to use negotiation skills where necessary & 1.4 \\
\hline I am able to provide leadership where necessary & 1.5 \\
\hline
\end{tabular}




\begin{tabular}{|c|c|}
\hline $\begin{array}{l}\text { Nine questions on intellectual skills used in the workplace in relation } \\
\text { to the course-level learning outcomes. (One question was open and } \\
\text { not noted here) }\end{array}$ & \\
\hline $\begin{array}{l}\text { I am confident at making accurate selection and application of fashion } \\
\text { management principles and procedures to solve a range of professional } \\
\text { situations and problems }\end{array}$ & 1.8 \\
\hline I can solve a variety of work-based problems autonomously & 1.5 \\
\hline $\begin{array}{l}\text { I am able to identify and classify principles and ideas within new work } \\
\text { situations }\end{array}$ & 1.5 \\
\hline $\begin{array}{l}\text { I am able to analyse ideas systematically, effectively and critically within } \\
\text { new work situations }\end{array}$ & 1.5 \\
\hline $\begin{array}{l}\text { I can develop ideas in support of well-structured arguments and in evolving } \\
\text { new concepts }\end{array}$ & 1.5 \\
\hline $\begin{array}{l}\text { I am able to integrate fashion management theory within professional } \\
\text { practice, for example, consumer behaviour }\end{array}$ & 1.6 \\
\hline $\begin{array}{l}\text { I am increasingly independent, confident and flexible in identifying and } \\
\text { defining complex problems }\end{array}$ & 1.5 \\
\hline $\begin{array}{l}\text { I am increasingly independent, confident and flexible in the application of } \\
\text { knowledge and skills appropriate for the job in hand }\end{array}$ & 1.4 \\
\hline I am able to synthesise facts and ideas into a well-structured argument & 1.5 \\
\hline $\begin{array}{l}\text { Six questions on key employability and transferability of skills to the } \\
\text { workplace in relation to the course-level learning outcomes. } \\
\text { (One question was open and not noted here) }\end{array}$ & \\
\hline $\begin{array}{l}\text { I can critically assess the nature of the interaction between the elements of } \\
\text { the creative, business and corporate activities }\end{array}$ & 1.6 \\
\hline $\begin{array}{l}\text { In undertaking my fashion research dissertation, I feel it has helped me } \\
\text { with my job role }\end{array}$ & 2.1 \\
\hline $\begin{array}{l}\text { I have the ability to synthesise areas of difficulty, contention and } \\
\text { controversy within my selected job }\end{array}$ & 1.6 \\
\hline $\begin{array}{l}\text { I can deal with complex ethical issues in accordance with my current } \\
\text { professional practice }\end{array}$ & 1.8 \\
\hline $\begin{array}{l}\text { I can deal with complex professional issues in accordance with my current } \\
\text { professional practice }\end{array}$ & 1.7 \\
\hline
\end{tabular}




\begin{tabular}{|l|c|}
\hline $\begin{array}{l}\text { Five questions on skills they feel they need more of in relation to } \\
\text { skills gaps highlighted from the qualitative feedback. (One question } \\
\text { was open and not noted here) }\end{array}$ & \\
\hline I feel I had enough digital skills development, such as creating web pages & $\mathbf{2 . 5}$ \\
\hline I feel I needed more development of numeracy skills & 1.8 \\
\hline $\begin{array}{l}\text { I feel I could have done with more development in group work considering } \\
\text { conflict and negotiation }\end{array}$ & $\mathbf{2 . 4}$ \\
\hline I feel I had enough development of soft skills, such as dealing with people & 1.8 \\
\hline
\end{tabular}

1 = strongly agree 5 = strongly disagree

The final section of the e-questionnaire (Table 7), which examined pre- and postgraduation views of alumni with regard to employability skills, highlighted small variances in most of the areas. A minimal variance is highlighted in 'dealing with groups in the workplace' $(\mathrm{Mn}=0.1)$.

Table 7. Means responses to variances in 'did you have enough training in' and 'did you want more training in' questions relating directly to these employability areas.

\begin{tabular}{|l|c|c|c|}
\hline \multicolumn{1}{|c|}{ Question } & $\begin{array}{c}\text { Mn before } \\
\text { graduation }\end{array}$ & $\begin{array}{c}\text { Mn after } \\
\text { graduation }\end{array}$ & Var \\
\hline $\begin{array}{l}\text { 14 questions in relation to the use of university } \\
\text { training provisions for personal development - } \\
\text { pre- and post-graduation. (Plus two open } \\
\text { questions) }\end{array}$ & & & \\
\hline Developing your Linkedln Profile & 1.9 & 1.6 & 0.3 \\
\hline Getting your CV work ready & 1.5 & 1.4 & 0.1 \\
\hline Interview techniques & 2.0 & 1.6 & 0.4 \\
\hline Assessment centre techniques & 2.0 & 2.0 & 0 \\
\hline How to complete an online job application & 1.9 & 1.8 & 0.1 \\
\hline How to deal with groups in the workplace & 1.9 & 1.8 & 0.1 \\
\hline
\end{tabular}

1 = strongly agree 5 = strongly disagree

The findings around professional/group work skills build upon the work of Hoadley and Kilner (2005) and Fearon et al. (2012), as it extends their research and highlights the need to manage teams in group work assessment sessions in a more 'workplace-relevant' 
manner. In light of the analysis of the data, the authors recommend that future university teaching should address skills development for students in digital literacy, digital storytelling and group collaboration (Table 8).

Table 8 - Author recommendations from the WEF and Hoadley and Kilner (2005) research (Gray, 2016; Hoadley and Kilner, 2005).

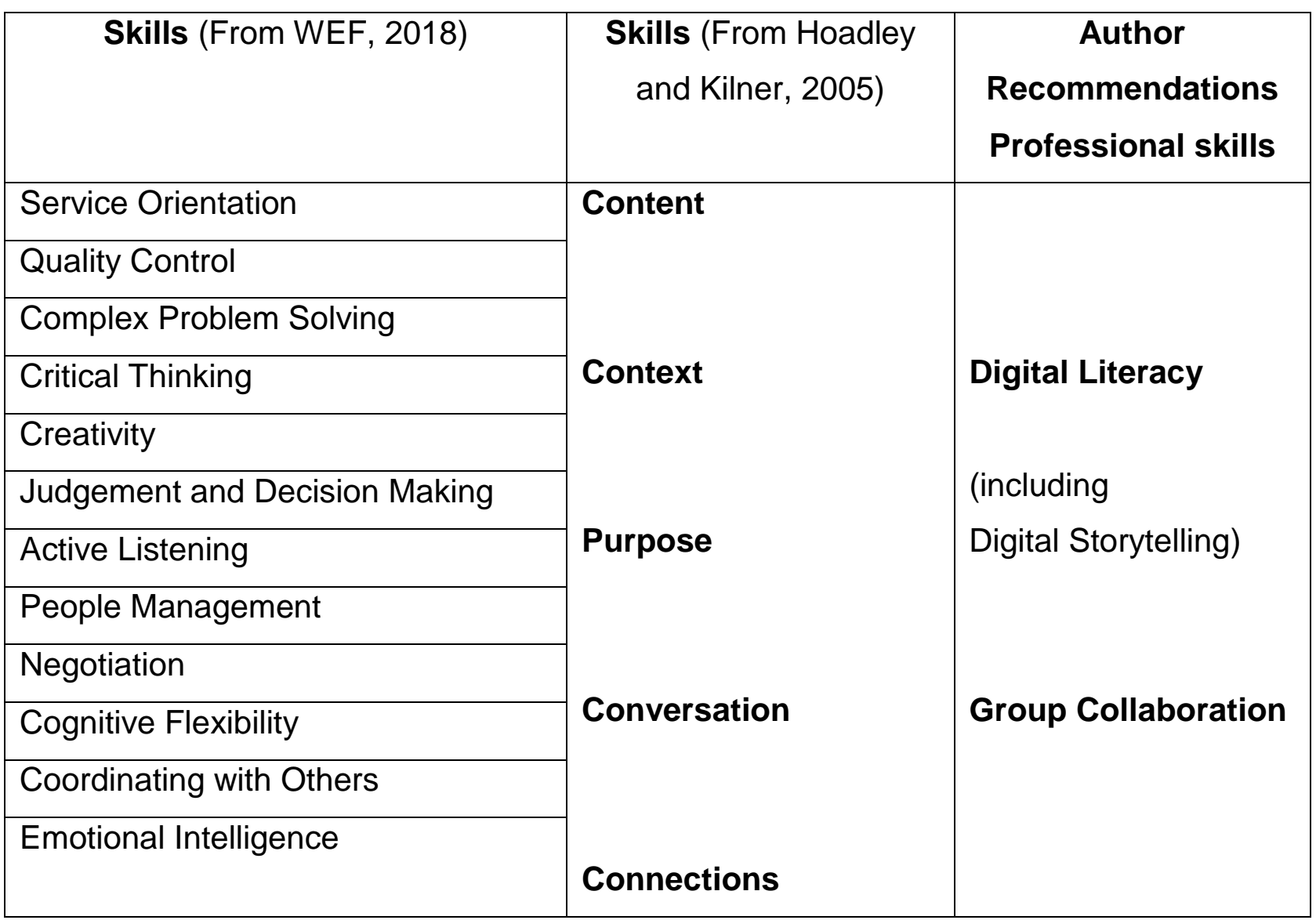

Taking this into account, as recommended by Bremner (2017; 2018), and reflecting upon the implications of the research for academia, a 'Communities 4 Practice' ethos, based on the C4P model (Figure 1) was piloted in a stage-four module on the FM degree (2018) in order to increase the level of professional /group skills transferability. A 'team' contract was deployed among the students in order to emulate work practice situations. This was welcomed by the external examiner, who commented that the approach was "providing a realistic scenario and assessment method for the students in terms of the work environment they will experience after leaving university". Students found this provided a much better structure to work with in their teams, noting that it facilitated some selfdirection and a more realistic approach (SEQ feedback). In 2019 this has been further 
developed, with the addition of a reflective section for students, which has yet to be evaluated.

\section{Digital skills gaps and employers' points of view}

The eight employer interviews (Table 5) provided some useful findings to support the embedding of digital skills. Firstly, in defining the term 'digital skills', the interviewees noted technical and functional aspects, citing the use of 'IT packages, typing' (17), 'content development, social media', (11/2) and 'digital communication and brand presentation' (I5) as key aspects. All eight employers highlighted the increasing need for company employees to have digital skills, and 'improving strategy, customer relationships' (14), data analysis and increasing profits were cited as benefits for the business. As interviewee 8 noted, this 'was driven in some cases by consumer demand'. The university interviewees noted that graduates are not always clear on what their digital literacy is, and are not always good at recognising their own digital skills. For example, 16 noted 'they have been taught to work with specific IT programmes such as Final Cut Pro but would not recognise this as a development in their digital literacy'. In terms of higher education, there was a general consensus, with six of the employer interviewees noting that universities should have some sort of 'digital' input in place in any degree discipline, which was in slight contrast to the remaining two interviewees from the marketing field (I 1 and 18 ), who indicated that only marketing-type courses needed digital skills input.

In terms of digital skills 'futures', all interviewees stressed the need for greater knowledge and ability with 'digital', highlighting that new employees should 'come prepared' for employment with appropriate digital skills, such as the ability to create content and data mine information. Yet training and development in these skills seems to be piecemeal and tends to revolve around what is needed technically, such as specific IT programmes, and on an ad hoc basis in a number of the companies interviewed. There was one exception in which a specific social communication company adopted a monthly training approach to digital skills development: 'we have a programme of relevant training and development on a monthly basis' (I1).

In addition, all of the employer interviewees $(\mathrm{Nl}=8)$ indicated that digital skills transferred within the workplace, although this was dependent on the type of employment (however, 
one SME owner stressed they are not 'benefiting from digital skills transfer' (I 5)). They felt they were not seeing the more useful skills being transferred to the workplace, that is graduates only know some IT programmes. Finally, digital skills were noted as very relevant for the future with the fast-paced nature of change, in particular the visualisation of data analytics. However, interviewees also noted the failure of universities to keep up with these changing digital skills. The employer interviewees ended with a strong suggestion that digital skills are necessary for company survival.

These findings build upon the works of Hounsell (2011), Laurillard et al. (2016), O'Leary (2015), Bennett et al., (2016), ECORYS UK (2016), Scottish Government and Price Waterhouse Cooper (2018) who all noted the need for digital skills in both learning and workplace contexts. The research enhances Jisc's (2014) definition of digital literacy, the works of Gallardo-Echenique et al. (2015) and supports the use of Beetham and Sharpe's framework (2010) in degrees, in order to aid educational development. In terms of collaboration it concurs with Employability in Scotland (2017) and the World Economic Forum (2018) need for a collective approach where educationalists and employers should work more closely together on course development to ensure there are no skills gaps. Finally it adds to the work of Bennett et al. (2016) and confirms the need for a rethink of education systems noted by the World Economic Forum $(2016,2018)$.

\section{Observations}

The above two sections of this paper highlight findings from qualitative and quantitative research which can be used in addition to the SEQs and NSS surveys. Whilst the SEQs and NSS give good data, this is obtained prior to first destination employment and may be used by students to comment negatively if they have received poor grades for their degree courses. They are a form of course satisfaction measure and do not necessarily highlight any gaps in course delivery, which in turn may affect student employability. However, this study's use of a mixed methods approach can enhance the NSS and SEQ data. For example, findings from this study have supported course development and the ILSR to confirm the introduction of more 'digitally skilled' focused modules. For professional /group skills, the C4P model has been adapted into a coursework assignment to make the scenario more representative of industry and integrates reflective practice. Evidence of successful implementation is a work in progress; however, two alumni from the 2018 
Fashion Management cohort are employed as a 'Digital Marketing Executive' at Porsche, and 'Content Developer' at a social communication company. This supports the points raised by the employer interviewees about graduates being digitally ready, coming prepared for the job in hand.

Wider research is required to ensure depth and breadth of information can be provided in relation to employability and the degree. At the strategic university level, research has been ongoing, using mixed methods approaches with key stakeholders (employers and students) to provide a 'bag of skills' required to meet the needs of a university graduate, and working towards the new proposed university graduate outcomes framework developed at strategic level. The issue for practitioners lies in the speed at which course changes can be implemented; if universities are to 'disrupt,' keeping pace with the speed of change, module changes maybe need to be more flexible.

\section{Recommendations}

Recommendations from this research are as follows.

\section{Collaboration with employers and flexibility in course development is required}

As new information has been identified, ongoing work is required to keep skills up to date on the FM degree. To do this successfully, collaboration and engagement with employers is key to this process. An employer champion could be sought for each module to support and enhance skills transferability and development outcomes. In addition, students could complete skills diaries to keep a log of what they have learned, what they need to learn, and how they are going to achieve this, as part of their learner journey. This could occur via a new IT programme used in our university which adopts this approach. On a more strategic level, universities and employers must collaborate more through partnerships to ensure the right group/professional /digital skills are incorporated for the future. This means employers need to work more closely with degree developers to future proof students, giving clarity on skill sets and outcomes requiring development in order to provide clearer graduate outcomes and attributes. It is clear that both employers and students need development in articulating their skills. However, this may mean that educationalists have to think 'outside of the box', as flexibility on LLOs may be required in order to deliver outcomes which respond to a disrupted workplace. 


\section{Use mixed methods research for employability skills feedback}

Taking on board the findings, it is clear that a mixed methods approach with a variety of sources is required to gather data, alongside the course feedback obtained, if universities are to make relevant changes to the degrees. It would be useful to interview the same respondents annually, for feedback on employability skills, how they have evolved, and how this may impact on the Fashion Management course, but logistically this may not be easy. Nevertheless, structured research should take place to ensure the modules deliver as many of these digital and group/professional skills as possible. As the fourth industrial revolution develops, new skills will develop, and requirements may change. The closing of the loop needs to be more effective.

\section{Conclusions}

The aim of this research was to explore and evaluate any skills gaps for stage 4 FM students transitioning into the workplace. While SEQ and NSS data provides useful information, it does not provide data from alumni who have moved into work, nor does it examine employers' perspectives. It was clear from the mixed methods research that the Fashion Management alumni believed that changes were required in relation to group/professional and digital skills within the degree programme. While some changes have been incorporated into the course, based on the research findings, further research is required to assess the impact. The additional employer research conducted added to the debate on the importance of digital skills and the need for future employees to begin work 'digitally ready'. It is therefore recognised that these mixed methods approaches are useful in ascertaining skills gaps, and this is a vital step in enhancing course development to aid in the development of flexible pedagogies and to move with the pace of industry. 


\section{References}

Beetham, H. and Sharpe, R. (2011) 'Digital Literacies Workshop'. Jisc Developing Digital Literacies Programme. Available at: https://www.jisc.ac.uk/full-guide/developingdigital-literacies (Accessed: 10 Dec 2019).

Bell, J. (2010) Doing your research project: a guide for first time researchers in education and social science. London: The Open University.

Bennett, D., Richardson. S. and MacKinnon, P. (2016) 'Enacting strategies for graduate employability: How universities can best support students to develop generic skill: Part B Appendices'. Australian Government Office for Learning and Teaching, Department of Education and Training [Online] Available at: https://melbournecshe.unimelb.edu.au/ data/assets/pdf file/0011/1874774/SP133258 Curtin Bennett Graduate-Employability Final-Report Part-A 20163.pdf (Accessed: 27 Oct 2019).

Black, J. (2013) 'From student to young professional: what to expect from working life', The Guardian, 24 June 2013. Available at: https://www.theguardian.com/careers/careers-blog/student-working-professionalguide-to-transition (Accessed: June 2016).

Bremner, P. A. M. (2017) 'From fourth year to the outside world: Are we making our fashion graduates 'work ready' - are their skills transferable into the workplace?', $3^{\text {rd }} Q A A$ International Enhancement in Higher Education Conference: Inspiring excellence transforming the student experience. QAA, Glasgow 6 - 8 June.

Bremner, P. A. M. (2018) 'The gap between degree outcomes and employability skills', $15^{\text {th }}$ QAA International Enhancement in Higher Education Conference: Evaluation, Evidence and Enhancement: Inspiring Staff and Students. QAA, Glasgow Caledonian University $7^{\text {th }}$ June.

Bryman, A. (2008) Social Research Methods. Oxford: Oxford University Press. 
Bryman, A. and Bell, E. (2015) Business research methods. 4th edn. Oxford: Oxford University Press.

CBI (2017) Helping the UK to thrive: CBI/Pearson Education and Skills Survey 2017.

Available at: https://www.bl.uk/collection-items/cbisc-helping-the-uk-thrive-2017 (Accessed: 11 December 2019).

CIPD (2017) Skills development in the UK workplace. Available at: https://www.cipd.co.uk/knowledge/work/skills/skills-factsheet, (Accessed: 10 May 2018).

CIPD (2019) Skills development in the UK workplace. Available at:

https://www.cipd.co.uk/knowledge/work/skills/skills-factsheet, (Accessed: 10 May 2018).

Crebert, G., Bates, M., Bell. B., Patrick, C. and Cragnolini, V (2004) ‘Developing generic skills at university, during work placement and in employment: graduates' perceptions', Higher Education Research \& Development, 23(2), pp.147-165.

Denscombe, M. (2014) The good research guide. Philadelphia: Open University Press.

ECORYS UK. (2016) 'Digital skills for the UK economy'. Department for Business Innovation and Skills, and Department for Culture Media and Sport. Available at: https://www.gov.uk/government/uploads/system/uploads/attachment data/file/4928 89/DCMSDigitalSkillsReportJan2016.pdf (Accessed: 16 June 2016).

Euromonitor Passport (2017) Digital consumer index: pinpointing the most promising digital opportunities. Available at: https://www.euromonitor.com/2017-digitalconsumer-index-pinpointing-the-most-promising-digital-opportunities/report (Accessed: 6 May 2018).

Euromonitor Passport (2018) Digital consumer index: pinpointing the most promising digital opportunities. Available at: https://go.euromonitor.com/white-paper-digitalconsumer-2019-digital-consumer-index-identifying-key-opportunities-for-digital- 
investment.html (Accessed: 20 January 2019).

FashionUnited UK (2018) Fashion Industry Statistics. Available at:

https://fashionunited.uk/uk-fashion-industry-statistics/ (Accessed: 7 June 2019).

Fearon, C., McLaughlin, H. and Eng, T. Y. (2012) 'Using student group work in higher education to emulate professional communities of practice', Education + Training, 54(2/3), pp.114-125.

Ferrari, A. (2012) Digital competence in practice: An analysis of frameworks. Luxembourg: Publications Office of the European Union.

Gallardo-Echenique, E., Minelli de Oliveira, J. Luis Marqués-Molias, L. and Esteve-Mon F., (2015) 'Digital Competence in the Knowledge Society', MERLOT Journal of Online Learning and Teaching, 11(1), pp.1-16.

Gray, A. (2016) 'The 10 skills you need to thrive in the Fourth Industrial Revolution'. World Economic Forum. Available at: https://www.weforum.org/agenda/2016/01/the-10skills-you-need-to-thrive-in-the-fourth-industrial-revolution/ (Accessed: 10 May 2018).

Hamill, J. (2018) 'The future of jobs in a world of Al and robotics', Leading Digital: Digital Leaders blog. Available at: http://www.futuredigitalleaders.com/blog/the-future-ofjobs-in-the-world-of-ai-and-robotics (Accessed: 10 May 2018).

Harvey L., Moon, S., Geall, V. and Bower, R. (1997) 'Graduates' Work: Organisation change and students' attributes', Birmingham: Centre for Research into Quality (CRQ) and Association of Graduate Recruiters (AGR).

High Fliers (2018) The Graduate Market in 2018. Available at: https://www.highfliers.co.uk/download/2018/graduate market/GMReport18.pdf (Accessed: 10 May 2018). 
Hinchcliffe. D. (2018) 'Designing the Digital Workplace for the End-to-End Employee Experience', Available at: https://dionhinchcliffe.com/2018/05/10/designing-thedigital-workplace-for-the-end-to-end-employee-experience/ (Accessed: 10 May 2018).

Hinchliffe, G. W. and Jolly, A. (2010) 'Graduate identity and employability', British Education Research Journal, 37(4), pp. 563 - 584.

Hoadley, C. M. and Kilner, P.G. (2005) 'Using technology to transform communities of practice into knowledge building communities', SIGGROUP Bulletin, 25(1), pp. 3140.

Hodgkinson-Williams, C., Stay, H. and Sieborger, I. (2008) 'Developing communities of practice within and outside higher education institutions', British Journal of Educational Technology, 39(3), pp. 433-442.

Hounsell, D. (2011) 'Graduates for the 21st Century: Integrating the Enhancement Themes' The Quality Assurance Agency for Higher Education 2011 Available at: http://www.enhancementthemes.ac.uk (Accessed: 10 May 2018).

Jackson, D. (2014) 'Testing a Model of Undergraduate Competence in Employability Skills and Its Implications for Stakeholders', Journal of Education and Work, 27(2), pp. 220-242.

Jackson, D. and Chapman E. (2012) 'Non-technical competencies in undergraduate business degree programs: Australian and UK perspectives', Studies in Higher Education, 37(5), pp. 541-567.

Jenkins, A., Vignoles, A., Wolf. A. and Galindo-Rueda, F. (2002) 'The Determinants and Effects of Lifelong Learning', Centre for the Economics of Education, London: London School of Economics and Political Science. 
Jisc (2014) Developing digital literacies. Available at:

https://www.Jisc.ac.uk/guides/developing-digital-literacies (Accessed: 15 May 2019).

Laal, M. and Salamati, P. (2012) 'Lifelong learning; why do we need it', Procedia - Social and Behavioral Sciences, 31, pp. 399-403.

Laurillard, D. Derrick, J. and Doel, M. (2016) Building digital skills in the FE sector. Available at:

https://assets.publishing.service.gov.uk/government/uploads/system/uploads/attach ment data/file/634181/Skills and lifelong learning digital skills in further education - Laurillard - final.pdf (Accessed 10 December 2019)

Lave, J. and Wenger, E. (1991) Situated Learning: Legitimate Peripheral Participation. New York: Cambridge University Press.

Linkedln (2018) Available at: https://www.linkedin.com/ (Accessed April 2018).

Maguire, S. and Guyer, C. (2004) 'Preparing Geography, Earth and Environmental Science (GEES) Students for Employment in the Enterprise Culture', Journal of Geography in Higher Education, 28(3), pp. 369-379.

Monster UK (2018) Available at: https://www.monster.co.uk/ (Accessed: April 2018).

Norton, S. (2016) Embedding employability in higher education for student success. Available at:

https://www.heacademy.ac.uk/system/files/downloads/employability viewpoint july 16 1.pdf (Accessed: 5 July: 2016).

O'Leary, S. (2017) 'Graduates' experiences of, and attitudes towards, the inclusion of employability-related support in undergraduate degree programmes; trends and variations by subject discipline and gender', Journal of Education and Work, 30(1), pp. 84-105. 
Price Waterhouse Cooper (2018) Employability guide. Available at:

https://www.pwc.co.uk/careers/documents/brochure-employability.pdf (Accessed: 10 May 2018).

Saunders, M., Lewis, P. and Thornhill, A. (2016) Research methods for business students. 6th edn. London: Prentice Hall.

Scottish Government (2016) Enhancing learning and teaching through the use of digital technology. Available at: https://beta.gov.scot/publications/enhancing-learningteaching-through-use-digital-technology/ (Accessed: 18 May 2018).

Skills Development Scotland (2019) 'Collective approach to skills must continue as new research shows digital economy growth', Employability in Scotland. Available at: https://www.skillsdevelopmentscotland.co.uk/news-events/2017/april/collectiveapproach-to-skills-must-continue-as-new-research-shows-digital-economy-growth/ (Accessed: 10 Dec 2019).

Walker, H. (2014) Employability Plus @RGU. Available at:

file:///C:/Users/Sarah/Downloads/StrategicStatementEmployabilityfinal.pdf (Accessed: 10 May 2018).

Wilton, N. (2012) 'The Impact of Work Placements on Skills Development and Career Outcomes for Business and Management Graduates', Studies in Higher Education, 37(5), pp. 603-620.

World Economic Forum (2018) Operating models for the future of consumption. Available at: http://www3.weforum.org/docs/WEF Operating Models for the Future of Consu mption.pdf (Accessed: 10 May 2018). 


\section{Author details}

Dr Pauline A M Bremner is a lecturer at Robert Gordon University in Aberdeen. She teaches in the School of Creative and Cultural Business, focusing upon the areas of Strategy, Internationalisation and Omni Channel Fashion. Her research interests encompass the skills development and skills transferability of graduates and the gift giving of toys to children within the sphere of consumption.

Dr Audrey Laing is a lecturer at Robert Gordon University in Aberdeen. She teaches in the School of Creative and Cultural Business, focusing upon the areas of Communication, Research Theory and Practice, and Consumer Psychology. Her research interests encompass the interaction of people and technology, and she undertakes ongoing research into the impact of digital disruption upon readers, bookshops and booksellers. 